\title{
A THOUSAND AND ONE VOICES: RE-READING SCHEHERAZADE IN CONTEMPORARY ARAB-AMERICAN FICTION
}

\author{
Gláucia Renate Gonçalves* \\ Universidade Federal de Minas Gerais \\ Cláudio Braga ${ }^{* *}$ \\ Universidade de Brasília
}

\begin{abstract}
In the wake of multiculturalism, the canon began to make room for the literary production of several groups of immigrants. Arab-American writers, however, remained marginal. Based on the notion of diaspora and its implications, this paper intends to investigate the literary production by Arab immigrants and their descendants in the United States with a view to discussing, in particular, the representation of gender. Through a brief discussion of a few contemporary works, we intend to show that Arab-American writers operate a kind of deessentialization, that is, their works offer gender representations that virtually oppose disseminated stereotypes of Arab peoples. It is our contention that the figure of Scheherazade is revised so as to create alternatives for characters who wish to claim new roles for themselves without giving up their diasporic belonging.
\end{abstract}

Keywords: Arab-American Fiction; Diaspora; Scheherazade

The Arab diaspora in the United States, comparatively speaking, is still largely without a terrain for critical investigation. In academia, Arab Americans are not the object of Middle East Studies, which focus on the Middle East itself and not the diaspora that originated in that area. They are not studied either in Ethnic Studies Programs, that tend to focus generally on Latinos, Asian-Americans, and Native-Americans, among others. Arab Americans are not the topic of investigation in American Studies Programs either, which only in the past few decades began to cross borders and admit that the term America refers to a much larger geographical territory than only the United States of America. This, by the way, takes us to the problem of terminology. Strictly speaking, the term Arab American should refer to Arab descendants throughout the Americas, from north to south, but it is commonly employed to refer to Arabs in the United States only, as a natural consequence of the term American being widely employed in the English language to refer to that particular country only.

It is, however, a fact that desdendants of Arabs in the United States are numerically significant and culturally active, as their literary production reveals. As they re-read the Arab traditions from new-both geographical and cultural-perspective, at the same time they contribute to a re-discovery of one part of the Americas: the United States. This new gaze undermines the cultural hegemony of mainstream America and renders audible diverse, if not dissonant, voices. These are the voices of hyphenated peoples, or bicultural subjects, whose "hypen" connects two elements whose relation can vary from a mode of tension to one of near balance. ${ }^{1}$

\footnotetext{
* Gláucia R. Gonçalves holds a Ph.D. in Literary Studies from the University of North Carolina at Chapel Hill. She is currently Associate Professor of Literatures in English at the Federal University of Minas Gerais, where she has been teaching since 1996. She is also a translator, and her research interests are memory studies and the representation of immigration and diaspora in American Literature. E-mail: grgoncalves@yahoo.com

${ }^{* *}$ Claudio Braga received his doctorate degree in Comparative Literature from the Federal University of Minas Gerais in 2010. He is currently Professor and researcher of Literatures in English at the University of Brasilia, Brazil. His research interests include literature and film, African postcolonial literatures in English, US immigrant writing, transnational and diasporic literatures. E-mail: braga.claudio@gmail.com
} 
The multiculturalist project of the 1970s contributed to an expansion of the literary canon of the United States, as it began to make room for works by writers representing several minority groups. Arab-American writers, however, remained somewhat marginal. While many schools and colleges began to include works by Latinos and by Asian Americans in their course syllabi, Arab-American literature up to this day is only studied in a few schools, particularly those in areas where the Arab community is larger, such as the greater Detroit, parts of California, and upstate New York.

Despite being relatively little known, the body of Arab-American literature dates back to the beginning of the twentieth century. The early writers of ArabAmerican descent formed a league known as the $A l$ Mahjar, whose key exponent was the well-known Khalil Gibran. According to Palestinian-American critic Lisa Suhair Majaj, the latter "were nonetheless primarily expatriate writers, exiles whose vision was trained in the Middle East and its literary and political contexts" (Majaj 68). Their works were mostly bilingual, and, though proud of their heritage, they lived in a context that approved of assimilation, which in part may explain the number of autobiographical pieces about their successful integration into mainstream American society.

Gibran Kahlil Gibran and his work The Prophet earned the Mahjar writers recognition and paved the road not only for a tradition of Arab-American poetry, but also for other genres. As Evelyn Shakir explains, The Prophet is built upon the "implicit claim that the Arab homeland is a fountainhead of wisdom and spirituality" (Shakir 5). Other Mahjar members, such as Abraham Rihbany, Mikhail Naimy, and Ameen Rihani were also instrumental in this first attempt at what we term "literary diplomacy" insofar as they helped to "promote cultural, social, and political reform in the East, based on the Western model, and to encourage a spiritual awakening in the West, based on the Eastern model" (Ludescher 98).

After this initial phase, Arab-American writing and its publication slowed down in the decades that followed, only to gain momentum as a result of the early 1970s pedagogical multiculturalism, which had already witnessed the voicing of other minority movements, such as the Civil Rights. It is against this backdrop that anthologies such as Wrapping the Grape Leaves: A Sheaf of Contemporary Arab-American Poets (1982) and Grape Leaves: A Century of Arab-American Poets (1988) were published, followed later by Post-Gibran: Anthology of New Arab-American Writing (1999) and Dinarzad's Children: An Anthology of Contemporary Arab American Fiction (2004), which undoubtedly conferred greater visibility upon the literature of the Arab diaspora in the United States.

In an essay entitled "New Directions for ArabAmerican Writing at Century's End," Majaj maps the literary production of Arab Americans and points out the need to diversify their writings in terms of genres. She mentions the scarcity, or at times absence, of performance pieces, children's literature, and drama. She also points out the need to approach themes still considered taboo, such as racialization, bilingualism, violence within the ethnic community, and gender issues.

In effect, Arab-American feminists are still trying to do away with the stereotypical image of the Arab woman largely disseminated in the Western media and the arts in general. One can think, for instance, of Henri Matisse's early twentieth-century paintings, whose odalisques appear "naturally" sensuous, with long hair, brightly colored accessories, and more often than not few clothes on. However, as Majaj points out, Arab-American feminists are sometimes misunderstood by their Western sisters, who mistakenly conclude that their rejection of male oppression symptomatically entails a rejection of the Arab tradition as a whole:

We need a stronger, more nuanced and less defensive articulation of feminism. ArabAmerican feminist critique has been hampered by the overwhelming array of orientalist stereotypes about Arab culture. When Arab and Arab-American women give voice to feminist concerns, they are often assumed, both by their own communities and by outside observers, to be rejecting their own cultural traditions in favor of a more "liberated" western culture. (73) 
Contemporary Diaspora Studies constitute a fertile ground for the discussion of gender relations and may shed light on the misunderstanding pointed out above. Among other theorists, James Clifford and co-editors Jana Braziel and Anita Mannur affirm that diasporic subjects today no longer necessarily wish to return to the land of their ancestors, that is, the mythic return to the past is not a conditio sine qua non. Assimilation, in its turn, is not embraced either. After all, as Avtar Brah affirms in Cartographies of Diaspora,

[a]t the heart of the notion of diaspora is the image of a journey. Yet not every journey can be understood as diaspora. Diasporas are clearly not the same as casual travel. Nor do they normatively refer to temporary sojourns. Paradoxically, diasporic journeys are essentially about settling down, about putting roots "elsewhere." (182)

Brah reiterates this idea when she proposes the notion of a "homing desire" as an alternative to returning to one's place of origin (180). In accordance with Brah, we firmly believe that the notion of home pertains to the timeframe of the future, not of the past. Always an arm's-length short of reach, home is the operating force behind diaspora subjects' "settling down", their everyday engagements.

At this point, Brah's definition of the "diasporic space" is equally useful for our discussion, for it aptly translates the terrain on which the immigrant and the native together negotiate their sense of belonging (Brah 181). This scenario is notable in the works of several Arab-American writers; in fact, it is represented as an inevitable choice down a long road of struggles.

Clifford, Brah, and Mannur remind us that women play a significant role in contemporary diasporas, whether as work force or as a cultural/social force that effects deep changes in the diasporic community as a whole. Moreover, as Floya Anthias argues, women are crucial agents in the process of passing on ethnic and nationalist ideologies, and, in the context of diaspora, it is in their hands to decide how to perpetuate traditions or even whether to perpetuate them (571). However, this is not to say that women are necessarily empowered in diaspora. Gayatri C. Spivak, in "Diasporas Old and New: Women in Transnational World", states that women are participants in a type of "diasporic subclass." According to the author, women in diaspora become "the superdominated, the super-exploited, but not in the same way" (249), meaning that patterns of oppression found in the homeland endure in diaspora and are, in fact, intensified and transformed. Such circumstances force women to remake their surviving strategies within and without their diasporic community.

In this essay, we intend to show that ArabAmerican writers-and especially Arab-American women writers-operate a kind of de-essentialization, that is, their works offer gender representations that virtually oppose disseminated stereotypes of Arab peoples and that are utterly in tune with contemporary approaches to diaspora. Having this in mind, we can begin to discuss the works of Arab-American writers in a more productive way, without running the risk of an essentialist or a nostalgic view. One fruitful way to do this is to revisit and revise the figure of Scheherazade, from the Thousand and One Nights, and her act of telling stories, or narrating, as a strategy to remain alive.

The story of the Thousand and One Nights, also known as the Arabian Nights, tells us of Shahryar, a Persian king who was shocked to discover that his wife had betrayed him. He then decides to marry a new virgin each day, only to have her executed the next morning before she possibly has a chance to betray him, too. He marries Scheherazade, who entertains her husband with the tales she tells. She begins a new tale each night but never quite finishes it, leaving the King curious about the outcome of the story and thus postponing her execution. This lasts for one thousand and one nights, and, despite variations in the numerous versions of the story, as is common in folk literature, in all of them the King ends up sparing Sheherazade’s life.

Scheherazade and Shahryar immediately come to mind as protagonists of this renowned work, which has been translated into dozens of languages. One character, though, that is hardly mentioned in discussions of the Thousand and One Nights is Dinarzad, Sheherazade's younger sister. In fact, it was Dinarzad who triggered the storytelling when she went into Scheherazade's 
room and asked her to tell one last story. Dinarzad herself does not narrate tales, as Scheherazade does. Though a silenced woman, Dinarzad is instrumental in creating the opportunity for another woman to speak.

It is our contention that Dinarzad and Scheherazade now reappear in Arab-American literature under a new guise. Emblematic of women's bond and of what Gayatri Spivak defines as "strategic essentialism", these figures are recast in the role of women characters who do speak for themselves or who equally devise schemes to help other women fight submission, going against the stereotype of the powerless and thus rendered silent Arab woman that prevails up until today. As Spivak argues, essentialism can become a strategic tool in order to achieve group empowerment and thus counter the dominance of patriarchy as well as of the colonial and neocolonial powers that be. In "Criticism, Feminism and the Institution", Spivak advises that those adopting essentialisms must be aware of their reductionism and untruthfulness, and should use them only temporarily, for the purposes of empowerment. Women characters in works by Arab-American writers do bond under a strategic homogeneity, only to undermine impositions and constraints of the old world and of their diasporic community.

As this paper will demonstrate, the recasting of women in these works takes effect, among other aspects, in the way traditional elements are reinterpreted in the American context. The fictional representation of Arab Americans reveals that the experience of diaspora effects deep changes in these subjects and in the way they structure themselves as a social group against the backdrop of newly acquired practices in the hostland. Their attitude towards language, for instance, is at times keenly marked. The representation of food may be emblematic of diasporic negotiations as well. The reconfiguration of gender roles too may take place, especially among members of the younger generation. Another noticeable change is the way the women characters dress themselves. After all, the way a community dresses tells us of its traditions and social hierarchies; clothing, in many Western and nonWestern societies alike, is at times even imposed as a means of social belonging, and it will certainly have a role to play in diaspora, as the selected works by Arab American writers will show.

West of the Jordan (2003), Laila Halaby's first novel, is narrated by four women characters-Hala, Khadija, Soraya and Mawal-who are cousins and tell their stories from different points of view. Hala was born in Jordan to a Jordanian father and a Palestinian mother, and later moved to the United States to study. The U.S.-born Khadija and Soraya grew up in the United States, while Mawal never left Nawara, Palestine, the birthplace of the four cousins' mothers.

Despite never having left the Arab world, Mawal becomes significant in this discussion insofar as she plays the role of a contemporary Scheherazade, telling her own story and stories of other women. One can easily argue that Mawal is directly affected by the diasporic experience: she often comments on how those that emigrated impact those who stay behind, and she is highly influenced by the contact she has with American culture through her relatives and other emigrants. In her assessment, "Nawara could have a smaller version of herself in the United States, which is like an army calling all able-bodied young men away and then never returning their bodies" (15).

More importantly, it is Mawal who conveys through her narrative the testimonies of other village women, often focusing on domestic violence. She narrates, for instance, the story of Farah and her first husband, "who gave her two children and fists that pounded her with welts to cover her body, welts she ignored or covered until it broke her father's heart and he convinced her husband to release her with divorce to freedom, but there is no freedom for a divorced woman with two children" (Halaby 51). Thus, of the four narrator cousins, it is Mawal who more poignantly discusses the condition of women. A reborn Scheherazade insofar as she is one of the narrators in the novel, she also acts as a new type of Dinarzad, as she listens attentively to the stories told by other women of her Palestinian community and which she incorporates into her own narrative. As she says, she "will keep [those secret stories of village women] safe and do no more than stitch them into the fabric of our rozas" (Halaby 17). 
As a matter of fact, it is also Mawal who explains the significance of the traditional dress in their community:

Everywhere is famous for something: political activism, delicious vegetables, ugly women. Our village is an island, famous for beautiful embroidered dresses that we call rozas while most everyone else calls them thobes, and yet surrounded by villages that do not embroider at all.

The complicated embroidery on our rozaswith both Palestinian and western stitches and patterns, captures the spirit of Nawara. (Halaby 15)

Embroidered dresses are indeed traditional in Palestine. Although it was considered sort of out of fashion for a while, the tradition of embroidering was revived in the latter decades of the twentieth century. During the first Intifada, as Iman Saca affirms, they became symbolic of national affiliation: "the colors of the Palestinian flag, and the word 'Palestine' embroidered on garments and other items became popular symbols of their homeland and national identity" (Saca 39).

The embroidered dress or tunic is meant to be worn over another layer of clothes. Hala, a character and one of the narrators in West of the Jordan, however, wears her roza directly over her naked body. As she confesses, she does so because of the climate:

My mother wore mostly western clothes-skirts and shirts or western dresses-but at home she liked dishdashes and this roza. I remember her wearing it and being happy. It is not a fancy one, but the pattern is clever and it suits me. I even imagine it still carries her scent. (I don't tell anyone that it is so hot that underneath it I am wearing only underwear-not a T-shirt and shalwar pants as my mother would wear.). (Halaby 203-4)

Although she does so for a practical reason, the act of wearing the roza only with her underwear certainly represents a transgression of the cultural tradition. At the same time, paradoxically, it symbolizes her wish to be in direct and unmediated contact with her tradition, to turn it into a kind of second skin, and, of course, her wish to be in contact also with her mother. It is thus through her clothes-and her narrative-that she performs agency. Hala, as it turns out, is the hyphenated character who most operates an exchange between the two sides of her bicultural experience.

Khadra Shamy, the protagonist of Mohja Kahf's The Girl in Tangerine Scarf (2006), puts on and takes off her hijab, the Muslim veil, as she too negotiates her bicultural condition. Despite the fact that as a child and teenager Khadra was rejected in part-and a significant part at that, since it was the most conspicuous sign of cultural affiliation she displayed-due to her Muslim clothing, she somewhat felt ennobled by wearing the veil:

The sensation of being hijabed was a thrill. Khadra had acquired vestments of a higher order. Hijab was a crown on her head. She went forth lightly and went forth heavily into the world, carrying the weight of a new grace $[\ldots]$, hijab soon grew to feel as natural to her as a second skin, without which if she ventured into the outside world she felt naked. (Kahf 112-13)

At his point Khadra could not see that the hijab exercised imposition upon women, and rather took it as a sign of her biological, as well as psychological, maturity. She embraced the practice in such a way that, out of her own will, she began to dress more and more soberly, both in the choice of item as well as in relation to dark colors she chose. At this point, the reader begins to notice that her attitude towards clothing parallels her questionings and assessment of religious practice, of marriage, and ultimately of the condition of women-as she falls in love for the first time, marries, has an abortion, and makes discoveries about the older women in her family.

After the sober phase, Khadra begins to wear more colors, skirts, blouses, and at a certain point, during a visit to Syria, she even stops wearing the hijab altogether. After dropping her scarf accidentally, she ponders "how veiling and unveiling are part of the same process, the same cycle, how both are necessary; how both light and dark are connected moments in the development of the soul in its darkroom" (309). More as a token of hybridity than of transgression, on the occasion of her return trip 
to the United States Khadra puts on an orange scarf and blue jeans, because "she wanted them to know at O'Hare [airport] that she was coming in under one of the many signs of her heritage" (313).

Another novel that de-essentializes gender is Crescent (2001), by the Jordanian-American Diana Abu-Jaber. Sirine, the main character, is an orphan who lives with her uncle. She takes up cooking and becomes a chef in a Los Angeles restaurant that serves Mediterranean food. In doing so, she performs a task that is traditionally associated with the private sphere of the home, and thus with women's role, but turns it into a professional activity-interestingly enough, she learned to prepare the traditional dishes from the Arab world not from her immigrant father, but rather from her American mother. As Sirine transgresses the essentialist view of Arab women as housewives, she uses cooking to achieve professional status and financial independence. Her love story with the Iraqi professor, a fugitive of Sadam Hussein's dictatorship, does not hinder her progress toward empowerment in any way, insofar as his demands in fact serve as a counterpoint to her self-determinism.

Abu-Jaber's Crescent has another element worth investigating in the discussion of Arab-American gender roles, though it is of a slightly different nature. Sirine's uncle is a male character in the novel who functions as a kind of Scheherazade "in trousers", that is, the male equivalent of the legendary storyteller, who tells the fantastic tale of a fugitive Persian slave from ancient times who immigrates to contemporary United States. Her uncle, consequently, blurs the line between the diegetic and hypodiegetic levels of the novel. More importantly, as a male Scheherazade, he allows Sirine to be a make-do Dinarzad, for it is to her that he tells his tale of the slave:

"If you behave," he tells his thirty-nine-year-old niece Sirine, "I'll tell you the whole story this time."

"You always say I'm too young to hear the whole story," Sirine says. She carves tiny bit of peel from a lemon for her uncle's coffee. .[...] He situates himself in his story-telling positionelbow on knee and hand to brow. (Abu-Jaber 15)
In the chapter that follows in the novel, her uncle finishes eating some tabbouleh salad, then has a ma'mul cookie, and begins the next chapter of the slave story. As one can notice, his oral narrative is intercalated with tastes from the food Sirine prepares, as life / nourishment / storytelling are intricately interwoven as the novel progresses.

Gregory Orfalea's "The Chandelier" (1984) too presents a male Scheherazade who tells us a story of hunger during war times in Lebanon. Exactly like Sirine's uncle in Abu-Jaber's novel, Mukhlis, the protagonist of Orfalea's story, is another male Scheherazade. Matile, his sister, keeps bringing more and more food to serve to her guests-Mukhlis and his wife Wardi, and Matile's grandson-as the brother recounts an episode from his childhood, when he travelled alone over the hills to try to find food for his starving mother and siblings. He came to an abandoned church and took a gold chandelier from it, which he had to drag to a nearby village in order to exchange it for some milk.

As the past of hunger in the old world and the present time of abundance of food in California are juxtaposed, here too nourishment appears in the form of food and of storytelling. On the diegetic level, the third-person narrator tells us that after immigration Mukhlis used to sing of his homeland to other members of the Arab diaspora, but the singing stopped when his mother died. Similarly, the narrative of the hypodiegetic level also stops when the climax of the tale is reached: the death by hunger of Mukhlis's youngest sibling, baby Wadie. In both instances, Mukhlis's sensibility is underscored, rendering a new picture of the Arab man. A story permeated with Christian symbolism, "The Chandelier" (1984) closes with an image that suggests a blessing of the Arab diaspora in the United States-a blessing of their meal, clearly connected with Mukhlis's act of remembering and of narrating the past: "They eat in silence, the unlit chandelier struck by the California sundown. It breaks into light above the food; it breaks in pieces of light on Mukhlis's almond head" (Orfalea 355).

Speaking of less rigid, or less stereotypical male figures, another character that comes to mind is Nazir, in Joseph Geha's short story "Monkey Business" (1990). Because of his sensitivity, Nazir, nicknamed 
Zizi, is not considered a "practical man" by the ArabAmerican community, and suffers tremendously after his wife's death:

When Samira was alive it had been a home. It had been a place where Zizi rediscovered what he'd had once before in his own father's housethe quiet, childlike confidence that here things would always be clean and, no matter what, he would be taken care of. It is this Zizi misses far more than the love in bed. (Geha 3)

In the end of the story, after nearly marrying a mail-bride from the old world, Nazir finds comfort in the company of his seven-year-old son, who puts on his deceased mother's wedding ring, takes off his father's shoes and prepares a nice and hot cup of coffee for him-like Nazir's late wife used to do, the same cup of coffee that epitomizes the feeling of home throughout the story. Although Nazir himself does not narrate-we have instead a third-person omniscient narrator-his fate is being sealed by the elderly in his family, as Scheherazade's fate was sealed by Shahryar. The narration of the thousand and one Arabian tales saved Scheherazade, while the narration of Nazir's predicament by the unknown narrator who possibly represents the voice of the Arab diaspora saved him from another arranged marriage.

These Arab-American diasporic writers allow contemporary Scheherazades to tell their stories, and give voice to characters who were formerly silent like Dinarzad, but who are now empowered and offer alternatives to gender and cultural oppression. Moreover, as the works mentioned above illustrate, it is worth emphasizing that not only the role of women is negotiated, but also men in the Arab-American community are viewed from a new angle, which we see as a significant step ahead in the discussion of gender in diaspora. While fiction does away with rooted stereotypes both of women and of men, these characters do not necessarily have to give up their identities as descendants of Arabs. Cultural clashes persist, as conflicts within the diaspora community itself continue, but as the homing desire is enacted, momentary comfort zones are created and nourish the possibility of the future at which Edward Said has signaled in Reflections on Exile:

Exile can produce rancor and regret, as well as a sharpened vision. What has been left behind may either be mourned, or it can be used to provide a different set of lenses. Since almost by definition exile and memory go together, it is what one remembers of the past and how one remembers it that determines how one sees the future. (xxxv)

Despite the demonization of Arabs as a result of the 1967 Arab-Israeli war, of the Gulf War, and of terrorist attacks, Arab Americans do not resort to positive icons or the Middle East as a form of compensation. As Scheherazades and Dinarzads of the Bush and Obama era, the fictional characters discussed here echo a thousand and one voices of Arab exiles in the United States who clamor to be heard and seen from a new perspective. Moreover, far from victimization, fictional works by Arab Americans have been able to move from the exemplary text of the collective experience and to a more subjective, personal focus, as today they present readers with a new form of agency through an effective reconfiguration of gender roles.

\section{Note}

1. The hyphen constitutes such a charged token in this scenario that it is worth mentioning that, throughout this essay, we will only leave it out in instances where grammatical rule dictates so: the hyphen should be used only when the term appears in adjective position (e.g. an Arab-American writer), while it is not used in the subject position (e.g. Arab Americans are part of the Arab diaspora).

\section{Bibliography}

Abu-Jaber, Diana. Crescent. New York: Harcourt, Brace \& Company, 2001. Print.

Anthias, Floya. "Evaluating 'Diaspora': Beyond Ethnicity?" Sociology. 32.3 (1998): 557-580. Print.

Brah, Avtar. Cartographies of Diaspora: Contesting Identities. London and New York: Routledge, 1996. Print.

Braziel, Jana E., and Anita Mannur. "Nation, Migration, Globalization: Points of Contestation in Diaspora 
Studies". Theorizing Diaspora: A Reader. Ed. Jana E. Braziel and Anita Mannur. Malden, MA: Blackwell, 2005. Print.

Clifford, James. "Diasporas." Cultural Anthropology 9:3 (1994): 302-38. Print.

Darraj, Susan Muadi. Scheherazade's Legacy: Arab and Arab American Women on Writing. Westport, CT: Praeger Publishers, 2004. Print.

Geha, Joseph. "Monkey Business." Through and Through: Toledo Stories. Saint Paul, Minnesota: Graywolf Press, 1990. 1-18. Print.

Halaby, Laila. West of the Jordan. Boston: Beacon Press, 2003. Print.

Kaldas, Pauline, and Khaled Mattawa (Eds.). Dinarzard's Children: An Anthology of Contemporary Arab American Fiction. Fayetteville: U of Arkansas P, 2004. Print.

Kadi, Joanna. "Introduction". Food for Our Grandmothers: Writings by Arab-Canadian Feminists. Ed. Joanna Kadi. Boston: South End Press, 1994. xiii- xx. Print.

Kahf, Mohja. The Girl in the Tangerine Scarf. New York: Carroll and Graf, 2006. Print.

Ludescher, Tanyss. "From Nostalgia to Critique: An Overview of Arab-American Literature.” MELUS. 31.4 (2006): 93-114. Print.

Majaj, Lisa S. "New Directions: Arab-American Writing at Century's End". Post-Gibran Anthology of New ArabAmerican Writing. Ed. Khaled Mattawa and Munir Akash. Syracuse, NY: Syracuse UP, 1999. 67-77. Print.

Orfalea, Gregory. “The Chandelier." Imagining America: Stories from the Promised Land. Ed. Wesley Brown and Amy Ling. New York: Persea, 2002. 345-55. Print.

Saca, Iman. Embroidering Identities: A Century of Palestinian Clothing. Chicago: U of Chicago P, 2006. Print.

Said, Edward. Reflections on Exile and Other Essays. Cambridge, MA: Harvard UP, 2000. Print.

Shakir, Evelyn. “Arab-American Literature”. New Immigrant Literatures in the United States: A Sourcebook to Our Multicultural Literary Heritage. Ed. Alpana Knippling. Westport: Greenwood Publishing Group, 1996. 3-18. Print.

Spivak, Gayatri C. "Criticism, Feminism and the Institution”. Thesis Eleven. 10.11 (1984-5): 175-89. Print.

. "Diasporas Old and New: Women in Transnational World”. Textual Practice. 2.10 (1996): 245-69. Print.
. The Spivak Reader: Selected Works of Gayatri Chakravorty Spivak. Ed. Donna Landry and Gerald MacLean. New York: Routledge, 1996. Print.

Recebido em: 28/05/2014 Aceito em: 06/10/2014 